\title{
PENELITIAN PEMBANTUUTAN BENIH IKAN BANDENG, Chanos chanos ASAL PANTI PEMBENIH DI TAMBAK
}

\author{
Tony Setiadharma") dan Yunus ${ }^{*}$ )
}

\begin{abstract}
ABSTRAK
Penelitian ini bertujuan untuk mengetahui pengaruh lama pembantutan terhadap pertumbuhan benih ikan bandeng asal panti pembenih yang dipelihara di tambak. Penelitian menggunakan rancangan acak lengkap dengan empat perlakuan dan tiga kali ulangan. Perlakuan yang diuji adalah benih yang dibantut selama satu, dua dan tiga bulan serta benih yang tidak dibantut. Benih dibantut di petak tambak pendederan berukuran $2 \times 1 \mathrm{~m}^{2}$ dengan padat penebaran, umur, bobot dan panjang standar masingmasing 2.000 ekor/petak; 25 hari; 0,0061-0,0078 g; dan 1,12-1,25 cm. Pakan berupa pelet dengan kandungan protein $28-30 \%$ diberikan dua kali sebanyak $10 \%$ dari total bobot badan per hari. Selanjutnya benih yang telah dan yang tidak dibantut dibesarkan di petakan tambak berukuran $20 \times 20 \mathrm{~m}^{2}$ dengan padat penebaran 500 ekor/petak dan masa pemeliharaan selama dua bulan.
\end{abstract}

Hasil penelitian menunjukkan bahwa benih yang dibantut selama satu bulan dan tidak dibantut memberikan hasil yang lebih baik $(\mathrm{P}<0.05)$ terhadap pertumbuhan panjang standar dan bobot dibanding dengan perlakuan lainnya. Oleh karena itu, lama pembantutan yang baik untuk benih ikan bandeng asal panti pembenih yang akan dibesarkan di tambak hendaknya tidak lebih dari satu bulan.

\section{ABSTRACT: Experiment in the Stunting of Hatchery Bred Milkfish, Cbanos cbanos Fry in Ponds. By: Tony Setiadharma and Yunus.}

The aim of experiment was to evaluate the effect of different period of stunting on the growth of milkfish fry reared in ponds. Four treatments, composed of the different periods of stunting, i.e. one, two and three months stunted and non stunted as a control, were allocated and replicated thrice. The design of experiment was set in a completely randomized design. The 25 day old fry hatchery of uniform size were stunted in $2 \times 1 \mathrm{~m}^{2}$ nursery ponds with a stocking density of $2,000 \mathrm{fry} /$ pond. The initial body weight and standard length of fry were $0.0061-0.0078 \mathrm{~g}$ and $1.12-1.25 \mathrm{~cm}$ respectively. The fry were fed with pelleted diet containing $28-30 \%$ protein, given twice a day at $10 \%$ of fry biomass per day. Thereafter, the stunted and non stunted fry were cultured in $20 \times 20 \mathrm{~m} 2$ grow out ponds with a stocking density of $500 \mathrm{fry} /$ pond. The culture experiment was terminated after two months.

Resulted showed that the body weight and standard length of one month stunted and non stunted milkfish fry were significantly higher $(\mathrm{P}<0.05)$ than those of the other two treatments. Therefore the best period for stunting of hatchery bred milkfish fry to be grown in the rearing pond was not more than one month.

\section{PENDAHULUAN}

Usaha budidaya ikan bandeng di Indonesia merupakan kegiatan yang tertua di Asia Tenggara dan kegiatan ini telah dimulai sekitar tahun 1400 (Kuo, 1985),

") Peneliti pada Loka Penelitian Perikanan Pantai Gondol, Bali. 
namun demikian produksi ikan bandeng masih rendah bila dibanding dengan di negara-negara lainnya seperti Filipina dan Taiwan. Luas tambak di Indonesia tercatat hampir sama dengan di Filipina, tetapi produksi ikan bandeng hanya $40 \%$ dari produksi di Filipina dan hanya $40 \%$ lebih tinggi dari produksi di Taiwan, yang luas tambaknya hanyak $10 \%$ dari luas tambak di Indonesia (Smith dan Chong, 1983).

Dengan pertimbangan bahwa rata-rata konsumsi protein per kapita masyarakat Indonesia masih rendah $(16 \mathrm{~kg})$ terutama protein hewani, maka pemerintah berupaya untuk meningkatkan produksi ikan bandeng sebagai satu di antara cara untuk meningkatkan konsumsi protein hewani. Selanjutnya tujuan pemerintah dalam hal usaha budidaya ikan bandeng baik secara intensif maupun ekstensif adalah untuk meningkatkan produksi, memperluas lapangan kerja, meningkatkan pendapatan dan taraf hidup masyarakat petani nelayan Indonesia.

Walaupun peranan usaha budidaya ikan bandeng cukup besar dalam kegiatan pembangunan perikanan Indonesia, namun demikian persediaan benih untuk budidaya di tambak masih sepenuhnya mengandalkan benih hasil tangkapan dari alam (Poernomo et al., 1985) sehingga hal ini dapat menimbulkan konsekuensi adanya persediaan benih yang tidak berkesinambungan serta harga benih yang sangat berfluktuatif yang menyebabkan usaha budidaya ikan bandeng tidak akan berkembang (Chong et al., 1983) dan karenanya dapat dimengerti bahwa usaha budidaya ikan bandeng di Indonesia selama ini tidak pernah bersifat intensif.

Dewasa ini teknik produksi benih ikan bandeng (nener) di panti pembenih telah berhasil dilakukan di Loka Penelitian Perikanan Pantai Gondol, Bali (Ahmad dan Sunyoto, 1990) dan teknik perbenihan ikan bandeng dapat dikembangkan dalam skala usaha (Cholik et al., 1990). A plikasi teknik produksi nener sudah mulai dikembangkan di masyarakat sejak pertengahan tahun 1992 dalam bentuk hatchery skala rumab tangga (HSRT) yang telah banyak berdiri dan beroperasi di Bali dengan produksi nener tiap siklus dapat mencapai 40.000-50.000 ekor (Ahmad et al., 1993).

Dengan dikuasainya teknik produksi nener di panti pembenih maka diharapkan di masa-masa yang akan datang produksi nener dapat meningkat sehingga dengan demikian dapat meningkatkan pasok nener bagi usaha budidaya ikan bandeng di tambak. Kualitas nener perlu mendapat perhatian terutama terhadap nener yang telah mengalami pembantutan. Penelitian ini dilakukan untuk mengevaluasi pengaruh lama pembantutan terhadap nener produksi panti pembenih yang dipelihara di tambak.

\section{BAHAN DAN METODE}

Kegiatan penelitian ini dilakukan di Instalasi Tambak Percobaan Loka Penelitian Perikanan Pantai (Lolitkanta) Gondol di Perancak, Negara, Bali. 
Tambak yang digunakan untuk pembantutan berukuran $2 \times 1 \mathrm{~m}^{2}$ sebanyak 9 petak. Benih ikan bandeng dari hasil pembenihan di Lolitkanta Gondol, Bali, ditebar pada masing-masing tambak sebanyak 2.000 ekor pada umur 25 hari, bobot antara 0,0061-0,0078 $\mathrm{g}$ dan panjang standar antara 1,12-1,25 cm per ekor. Penebaran benih dilakukan secara bertahap untuk mendapat perlakuan lama pembantutan yang berbeda. Selama masa pembantutan benih diberi pakan buatan berupa pelet dengan kandungan protein, lemak, serat, abu dan kadar air masing-masing $28-30 ; 5-8 ; 4-6 ; 5-8$ dan $11-13 \%$ yang tersusun dari bahan tepung ikan, bungkil kedele, gandum, dedak, vitamin, mineral dan antioksidan. Pakan diberikan sebanyak $10 \%$ dari total bobot badan per hari dan diberikan pada pagi dan sore hari.

Setelah masa pembantutan selesai, benih selanjutnya ditebar di tambak pembesaran. Tambak yang digunakan untuk pembesaran benih berukuran $20 \times 20 \mathrm{~m}^{2}$ sebanyak 12 petak dengan penebaran benih sebanyak 500 ekor/petak. Penelitian menggunakan rancangan acak lengkap dengan empat perlakuan dan setiap perlakuan diulang tiga kali. Perlakuan penelitian adalah benih ikan bandeng yang dibantut selama satu, dua dan tiga bulan serta benih yang tidak dibantut.

Sebelum benih ditebar, dilakukan persiapan tambak meliputi pengolahan tanah dasar, pengapuran, pemberantasan hama dan pemupukan awal menurut petunjuk yang telah ditentukan (Anonimous, 1991). Pupuk yang digunakan untuk menumbuhkan makanan alami adalah urea, TSP dan pupuk kandang. Setelah benih ditebar pemupukan susulan dilakukan setiap dua minggu. Pemeliharaan benih berlangsung selama dua bulan.

Pada akhir penelitian dilakukan pengamatan terhadap bobot dan panjang badan ikan. Pengukuran panjang badan ikan berdasarkan panjang standar dilakukan dengan mengukur jarak garis lurus antara ujung mulut paling depan sampai ujung pangkal ekor. Pengamatan kualitas air untuk mendapatkan data penunjang meliputi suhu, salinitas, $\mathrm{pH}$, oksigen terlarut, nitrit, total amonia dan kecerahan air.

\section{HASIL DAN PEMBAHASAN}

Pada akhir masa pemeliharaan benih selama dua bulan, panjang standar dan bobot rata-rata ikan bandeng pada setiap perlakuan dapat dilihat pada Table 1. Panjang standar rata-rata ikan bandeng tertinggi dicapai pada perlakuan benih yang dibantut selama satu bulan, yaitu $7,82 \mathrm{~cm}$ kemudian diikuti perlakuan tidak dibantut, dibantut selama dua dan tiga bulan masing-masing dengan panjang standar rata-rata $7,78 \mathrm{~cm} ; 4,45 \mathrm{~cm}$ dan $3,33 \mathrm{~cm}$. Panjang standar ikan bandeng pada perlakuan benih yang dibantut selama satu bulan dan yang tidak dibantut tidak menunjukkan perbedaan $(P>0.05)$, tetapi kedua perlakuan tersebut berbeda nyata $(\mathrm{P}<0.05)$ terhadap perlakuan benih yang dibantut selama dua dan tiga bulan. 
Table 1. Standard length and weight of milkfish after rearing for two months in ponds using fry stunted with different period

\begin{tabular}{cccc}
\hline $\begin{array}{c}\text { Period of stunting } \\
\text { (month) }\end{array}$ & Replicate & $\begin{array}{c}\text { Standard length } \\
\text { (cm/ind.) }\end{array}$ & $\begin{array}{c}\text { Weight } \\
\text { (g/ind.) }\end{array}$ \\
\hline 0 & 1 & 6.90 & 8.35 \\
& 2 & 7.65 & 8.97 \\
& 3 & 8.80 & 6.80 \\
& Average & $7.78^{a}$ & $8.04^{a}$ \\
1 & 1 & 6.35 & 4.47 \\
& 2 & 7.82 & 6.65 \\
& 3 & 9.30 & 8.85 \\
& Average & $7.82^{a}$ & $6.66^{a}$ \\
& 1 & 3.20 & 0.43 \\
& 2 & 4.45 & 1.42 \\
& 3 & 5.70 & 2.42 \\
& Average & $4.45^{b}$ & $1.42^{b}$ \\
3 & 1 & 2.55 & 0.48 \\
& 2 & 3.35 & 0.46 \\
& 3 & 4.10 & 0.68 \\
& Average & $3.33^{b}$ & $0.54^{b}$ \\
\hline \hline
\end{tabular}

Note: * means in a column followed by a common superscript are not significantly different $(P>0.05)$

Bobot rata-rata ikan bandeng pada perlakuan benih yang tidak dibantut adalah yang tertinggi, yaitu $8,04 \mathrm{~g}$ kemudian menyusul perlakuan yang dibantut selama satu, dua dan tiga bulan masing-masing dengan bobot rata-rata 6,66 g; 1,42 g dan 0,54 g. Bobot rata-rata ikan bandeng pada perlakuan benih yang tidak dibantut dan yang dibantut selama satu bulan tidak berbeda $(\mathbf{P}>0.05)$, tetapi kedua perlakuan tersebut berbeda nyata $(P<0.05)$ terhadap perlakuan benih yang dibantut selama dua dan tiga bulan.

Hasil penelitian Tuburan (1989) menunjukkan bahwa benih ikan bandeng yang dibantut selama dua, tiga dan enam bulan memberikan hasil yang berbeda tidak nyata dengan yang tidak dibantut terhadap rata-rata, kelangsungan hidup dan produksi setelah benih dipelihara di tambak luasan $144 \mathrm{~m} 2$, dengan kepadatan 2.777 ekor/ha dan lama pemeliharaan tiga bulan. Selanjutnya dari hasil penelitian Lijauco et al. (1978 dalam Mustafa dan Mangampa, 1990) benih ikan bandeng yang dibantut selama satu tahun tidak memberikan pengaruh yang nyata terhadap pertumbuhan bobot dibanding dengan benih yang tidak dibantut setelah dipelihara di tambak selama 135 hari. Hal ini diduga benih ikan bandeng yang digunakan berasal dari benih alam, yang mempunyai 
vitalitas yang baik sebagai hasil seleksi alam, mulai dari hidup pada lingkungan tempat pemijahan di laut bebas sampai berada di perairan pantai. Bagarinao (1991) mengemukakan bahwa larva yang telah berhasil menuju perairan pantai dari perairan laut bebas minimal mempunyai panjang total dan umur sekitar $10 \mathrm{~mm}$ dan dua minggu. Dengan vitalitas yang baik yang dimiliki oleh benih alam maka walaupun dibantut selama satu tahun benih tersebut masih dapat bertumbuh secara normal setelah dibesarkan di tambak.

Benih ikan bandeng yang berasal dari panti pembenih secara karakteristik menunjukkan adanya perbedaan dibanding dengan benih yang berasal dari alam. Kohno dan Duray (1989) mengemukakan bahwa benih yang berasal dari alam berbadan ringan, mempunyai kecepatan berenang 108,79 $\pm 39,109$ $\mathrm{cm} /$ menit dan gerakannya cepat, sedangkan benih yang berasal dari panti pembenih berbadan berat, mempunyai kecepatan berenang $76,64 \pm 47,826$ $\mathrm{cm} /$ menit dan gerakannya lambat. Crim dan Peter (1988 dalam Sumiarsa, 1994) menyatakan bahwa benih yang diproduksi secara alami sebagian besar adalah benih yang sehat dibanding dengan benih yang diproduksi dengan menggunakan teknik perangsangan. Sedangkan menurut Sumiarsa (1994) terdapat perbedaan toleransi yang tidak nyata terhadap uji stres salinitas, suhu dan transportasi pada benih ikan bandeng yang berasal dari alam dan benih yang diproduksi panti pembenih.

Dalam penelitian ini benih ikan bandeng yang digunakan berasal dari panti pembenih dan ternyata benih yang dibantut selama satu bulan menunjukkan pertumbuhan panjang standar dan bobot yang relatif sama dengan yang tidak dibantut setelah dibesarkan di tambak selama dua bulan. Hal ini disebabkan benih ikan bandeng tersebut masih mempunyai vitalitas yang baik sehingga mampu bertumbuh secara normal. Dibanding dengan benih yang tidak dibantut dan yang dibantut selama satu bulan, benih ikan bandeng yang dibantut selama dua dan tiga bulan diduga vitalitasnya menjadi semakin turun sehingga menyebabkan pertumbuhan panjang standar dan bobot secara nyata menjadi lebih rendah.

Dengan demikian pembantutan benih ikan bandeng asal panti pembenih dapat memberikan manfaat dalam menunjang pengadaan benih untuk budidaya ikan bandeng dengan cara membeli benih pada saat produksi benih di panti pembenih berlebihan untuk dibantut paling lama satu bulan, kemudian dapat digunakan sebagai sediaan benih untuk keperluan penebaran di tambak.

Hasil pengamatan kualitas air selama penelitian berlangsung menunjukkan kisaran suhu antara $24,8-28,2^{\circ} \mathrm{C}$; salinitas $22-30 \mathrm{ppt}$; $\mathrm{pH} 7,78-8,05$; oksigen terlarut 4,5-6,8 ppm; nitrit $0,0038-0,0350 \mathrm{ppm}$; total amonia $0,008-0,020 \mathrm{ppm}$ dan kecerahan air $30-40 \mathrm{~cm}$. Kondisi kualitas air tersebut masih berada dalam batasbatas yang normal untuk kehidupan ikan bandeng. 


\section{KESIMPUL.AN}

1. Benih ikan bandeng asal panti pembenih yang dibantut selama satu bulan dan yang tidak dibantut memberikan hasil yang lebih baik $(P<0.05)$ terhadap pertumbuhan panjang standar dan bobot dibanding dengan benih yang dibantut selama dua dan tiga bulan setelah benih dipelihara di tambak selama dua bulan.

2. Pembesaran benih ikan bandeng asal panti pembenih di tambak dapat menggunakan benih yang dibantut dengan lama pembantutan yang baik tidak lebih dari satu bulan.

\section{DAFTAR PUSTAKA}

Ahmad, T. dan P.Sunyoto. 1990. Status and prospect of marine aquaculture in Indonesia. Indonesian Agricultural Research and Development Journal 12(3):47-53.

Ahmad, T., A.Priyono, T.Aslianti, T.Setiadharma dan Kasprijo. 1993. Pedoman teknis perbenihan ikan bandeng. Seri Pengembangan Hasil Penelitian Perikanan No.PHP/KAN/24/1993, Badan Litbang Pertanian, Jakarta. 73 hal.

Anonimous. 1991. Penggelondongan ikan bandeng di tambak. Pusat Penelitian dan Pengembangan Perikanan. Jakarta. 8 hal.

Bagarinao, T.U. 1991. Biology of milkfish (Chanos chanos Forsk.) SEAFDEC, Aquacult. Dept. Iloilo, Philippines. 94 p.

Cholik, F., Z.I.Azwar, A.Priyono, G.Sumiarsa, Badraeni dan S.N.Irianti. 1990. Teknologi pembenihan ikan bandeng (Chanos chanos Forsk.). Subbalai Penelitian Budidaya Pantai Gondol, Bali. 46 hal.

Chong, K.C., A.Poernomo and F.Kasryno. 1983. Economic and tecnological aspects of the Indonesian milkfish industry. p. 199-213. In Juario, J.V., R.P.Ferraris and L.V.Benitez (Eds.), Advances in milkfish biology and culture. Island Publishing House Inc., Metro Manila, Philippines.

Kohno, H. and M.Duray. 1989. Schemea of future milkfish studies with emphasis on qualitative characteristics of larvae. SEAFDEC Asian Aquaculture 11(2):5-8.

Kuo, C.M. 1985. A review of induced breeding of milkfish. p. 57-77. In Lee, C.S. and I.C. Liao (Eds.) Reproduction and culture of milkfish, Oceanic Institute, Hawaii and Tungkang Marine Lab., Taiwan.

Mustafa, A. dan M.Mangampa. 1990. Usaha budidaya udang tambak menggunakan benur windu, Penaeus monodon yang berbeda lama pembantutan. J. Penel. Budidaya Pantai 6(2):35-48. 
Poernomo, A., A.E.Vanstone, C.Liem, N.A.Giri, Tridjoko and A.Prijono. 1985. Natural spawning, larva rearing and rematuration of captive milkfish (Chanos chanos Forsk.) in Indonesia. 15 p. (unpublished).

Smith, I.R. and K.C.Chong. 1983. Southeast Asian milkfish culture: economic status and prospects. p. 1-20. In Juario, J.V., R.P.Ferraris and L.V.Benitez (Eds.), Advances in milkfish biology and culture. Island Publishing House Inc., Metro Manila, Philippines.

Sumiarsa, G.S. 1994. Tolerance of the hatchery-bred and natural milkfish fry, Chanos chanos toward various stress test. J. Penel. Budidaya Pantai 10(1):8594.

Tuburan, I.B., 1989. Significance of stunting milkfish. SEAFDEC Asian Aquaculture 11(2):8-12 
